\title{
VI Jornadas de Estudio sobre pensamiento, cultura y sociedad colonial
}

\section{Margarita Suárez}

\section{(2) OpenEdition}

1 Journals

\section{Edición electrónica}

URL: http://journals.openedition.org/bifea/5682

DOI: $10.4000 /$ bifea.5682

ISSN: 2076-5827

\section{Editor}

Institut Français d'Études Andines

\section{Edición impresa}

Fecha de publicación: 1 mayo 2005

Paginación: 133

ISSN: 0303-7495

\section{Referencia electrónica}

Margarita Suárez, « VI Jornadas de Estudio sobre pensamiento, cultura y sociedad colonial », Bulletin de l'Institut français d'études andines [En línea], 34 (1) | 2005, Publicado el 08 abril 2005, consultado el 02 diciembre 2020. URL : http://journals.openedition.org/bifea/5682 ; DOI : https://doi.org/10.4000/ bifea. 5682

\section{(c) $(7)(9$}

Les contenus du Bulletin de l'Institut français d'études andines sont mis à disposition selon les termes de la licence Creative Commons Attribution - Pas d'Utilisation Commerciale - Pas de Modification 4.0 International. 


\section{Eventos}

\section{JORNADAS DE ESTUDIO SOBRE PENSAMIENTO, CULTURA Y SOCIEDAD COLONIAL}

Con el auspicio del IFEA y la Pontificia Universidad Católica del Perú, se llevaron a cabo las VI Jornadas de estudio sobre pensamiento, cultura y sociedad coloniales bajo el título «Las dimensiones del imperio: redes e intercambios en la América hispánica». Las sesiones se realizaron entre el 30 de setiembre y el 2 de octubre de 2004 en el Instituto Riva-Agüero y en la Hacienda Ocucaje, Ica.

El objetivo de estas VI Jornadas fue explorar las redes y conexiones que se establecieron en la América colonial desde diferentes disciplinas y desde múltiples facetas. Las ponencias trataron sobre la circulación de imágenes, ideas y bienes — que incluyeron temas relativos a la cultura material y a las formas de transmisión e intercambio de códigos culturales e ideas - y se discutió acerca de las prácticas de poder, tanto en el ámbito criollo como en el mundo indígena.

Hubo seis mesas temáticas de debate: «Figuras y símbolos en el Arte colonial», «Redes y circuitos imperiales», «Las prácticas de poder», «Palabras e imágenes del mundo indígena», «Circulación de ideas y conocimientos», y «Ética, política y sociedad». Entre las ponencias presentadas estuvieron «Conocimiento global, visión imperial: las redes comerciales e imperiales en el marco de la crisis del siglo XVII» (Daviken Studnicki), «Las exhalaciones de la madre tierra. Las ciencias de la tierra en el Perú de los siglos XVI al XVIII» (Carmen Salazar), «Libros y comercio en Lima en el período tardío colonial» (Pedro Guibovich), «Cultura del don y poder en América colonial» (Alejandro Cañeque), «Poder, negociación y corrupción en el Perú colonial» (Margarita Suárez), «La regulación de las prácticas teatrales durante el gobierno del Conde de Lemos» (José A. Rodríguez Garrido), «Circuitos culturales: los nexos epistemológicos entre las mujeres piadosas en Lima, siglo XVII» (Nancy van Deusen), «De Cajamarca a Huarina: imágenes conflictivas de la escritura y de la identidad en tres textos coloniales» (Carmela Zanelli), entre otras. 